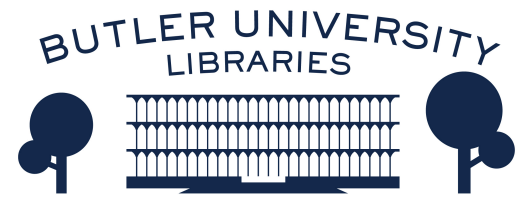

Journal of Hindu-Christian Studies

\title{
Cultural Interactions and Religious Iconography in 16th Century Kerala: the Mural Paintings of St. Mary's Church in Angamaly
}

\author{
Patrizia Granziera \\ University of Morelos
}

Follow this and additional works at: https://digitalcommons.butler.edu/jhcs

Part of the Christianity Commons, Hindu Studies Commons, and the History of Art, Architecture, and Archaeology Commons

\section{Recommended Citation}

Granziera, Patrizia (2017) "Cultural Interactions and Religious Iconography in 16th Century Kerala: the Mural Paintings of St. Mary's Church in Angamaly," Journal of Hindu-Christian Studies: Vol. 30, Article 10. Available at: https://doi.org/10.7825/2164-6279.1662

The Journal of Hindu-Christian Studies is a publication of the Society for Hindu-Christian Studies. The digital version is made available by Digital Commons @ Butler University. For questions about the Journal or the Society, please contact cbauman@butler.edu. For more information about Digital Commons @ Butler University, please contact digitalscholarship@butler.edu. 


\title{
Cultural Interactions and Religious Iconography in $16^{\text {th }}$ Century Kerala: the Mural Paintings of St. Mary's Church in Angamaly.
}

\author{
Patrizia Granziera \\ University of Morelos
}

ST. MARY'S Jacobite Syrian Church is an ancient church in Angamaly (Kerala). One account has Syrian Christians arriving in Angamaly in $384 \mathrm{CE}$ and the church being established in $409 \mathrm{CE}$. Syrian Christians are the earliest Christian community of India, and they attribute their origin to the evangelical efforts of the apostle Saint Thomas who is believed to have travelled through the Malabar country in $52 \mathrm{CE}$ evangelizing and building churches. It was when he moved east that he is supposed to have met his death and (martyrdom) at Mylapore near Madras.

The early church architecture in Kerala embraced several indigenous features: painted woodcarving, oil lamps, and metal utensils fashioned in local styles. Churches were built in teakwood (as with Kerala Hindu temples).
In 1498 Vasco de Gama landed for the first time in Calicut (Kerala), and with the Portuguese conquest of Goa in 1510 a new chapter in the history of Christian art and architecture began in South India.

The original paintings of these first Christian churches do not exist any longer. However some of them, like St Mary's Church in Angamaly, possess mural paintings that date back to the $16^{\text {th }}$ century. Although through the centuries and to this day this church has been a bastion of the Syrian Orthodox Christians of Malankara, the church murals reveal a style and technique that shows similarities with Christian art of Catholic Portugal and Spain.

The Malankara Christian Orthodox Church was apparently founded by St Thomas. From the fourth century this Indian Church entered into

Patrizia Granziera is Professor of Art History at the University of Morelos, Cuernavaca, Mexico. She has a Ph.D. in Art History from the University of Warwick (England). Her research focuses on the iconography of gardens and landscapes and on the image and symbolism of the divine feminine. She has published widely on these topics in journals such as the Journal of Intercultural Studies, Garden History, Landscape Research, Studies in World Christianity, Journal of Esoteric Studies, Toronto Journal of Theology, Comparative Studies of South Asia, Africa, and the Middle East, Estudios de Asia y Africa, COLMEX, and Colonial Latin American Review. In addition, she has co-authored a book, Aztec Goddesses and Christian Madonnas: Images of the Divine Feminine in Mexico (Routledge 2012). She spent part of her two sabbatical years in South India and Indonesia doing research on the divine feminine.

Journal of Hindu-Christian Studies 30 (2017): 83-99 
a close relationship with the Persian or East Syrian Church. From the Persian Church the Indians inherited East Syrian language and liturgies and gradually came to be known as Syrian Christians. ${ }^{1}$

Centuries later, when the Portuguese landed in India, they met the Christians of St. Thomas. They set great hopes on the St. Thomas Christians. These Christians, too, on their part were pleased at the arrival of powerful Christians from the West and desired Portuguese help to strengthen their own privileged existence in India. When Vasco da Gama arrived at Cochin on his second voyage (1502), a delegation of Thomas Christians went to meet him and implored his protection. This cordial and intimate relation continued for two decades. However, when the Portuguese travelled throughout Kerala and entered the Churches of St. Thomas Christians, they realized that these Christians were neither subject to Rome nor were they similar in their Church traditions. They found that these Christians were followers of the East Syrian Church, Eastern bishops looked after them, and the Patriarch in Babylon was considered their ecclesiastical head. ${ }^{2}$ Moreover, they thought that since the East Syrian Church was Nestorian, Indian Christians were heretics. Since the Pope, through the 'Padroado,' had granted to the Portuguese crown sovereign rights over the eastern lands they conquered, the Portuguese thought that the Thomas Christians should be under their control. When the Portuguese arrived in Kerala (in the 16th century), there were about a dozen bishops from the East Syrian Church. Mar Jacob, the last one of these East Syrian bishops, led the Church of St. Thomas till his death in $1552 \mathrm{CE}$. After his death, the Roman Catholics intensified their efforts to subdue the
Church of St. Thomas by preventing any new arrival of bishops from Babylon. Finally, they forced St. Thomas Christians to meet in the Synod of Udayamperoor (1599), where it was declared that they would be under Roman rule from then on. Until 1653 three Jesuit bishops ruled over the St. Thomas Christians, executing the decrees of the synod and forcing the Malabar Church to become Roman Catholic. ${ }^{3} \mathrm{~A}$ Latin bishop was appointed to lead the Church of St. Thomas, and the Metropolitan status of Angamali was suppressed, becoming subordinate to Goa. However, this did not last long, since in 1653, under the leadership of their Archdeacon, the Thomas Christians rejected all connections with the Portuguese Roman Catholics at an Oath called Koonen Cross on January 3, 1653, at Mattanchery near Kochin. ${ }^{4}$

It was probably during the years of subjection to the Portuguese "Padroado" that the walls of St. Mary's church in Angamaly were painted. This could explain the European iconography and style. The author could have been a converted Indian who was trained by a Portuguese priest. Eastern Orthodox Churches in fact are usually decorated with icons, few use mural paintings, and when they do their paintings imitate the style of icons. St. Mary's murals reveal a very different style.

One enters the church from a side door. The murals of the main hall represent on the right Christ and St. Thomas instructing an Indian probably belonging to a high caste. Unfortunately a window opening on the same wall has damaged much of the painted surface. On the left two scenes illustrate the incredulity of St. Thomas and Jesus' Ascension into Heaven. This last panel was also damaged due to the opening of a window on the same wall. (fig.1-2) Paintings on the walls near the apse deal with 
the life of Christ starting on the right with Christ praying in the garden, his arrest and flagellation. On the opposite wall we find scenes of his crucifixion and resurrection in addition to the portrait of a bishop identified with St. Mar Thoma (fig. 3). Carved wooded ceilings adorn both sides of the altar entrance. Although they look like European Renaissance coffered ceiling, the flower appearing in the centre of the coffer is a lotus (fig. 7). In Hindu iconography, the lotus is a powerful symbol of purity, and knowledge; it represents spiritual perfection and authority which rises above worldly contamination. The Hindu ornamentation uses this motif in the most conventional or stylized shape. There are other elements in this church that reveal a similarity to Kerala temple painting like the limited use of colours, usually malachite green, red and ochre and the heavy decorative borders dividing the pictures space.

A special feature common to all St. Thomas Christians' churches is the separation of the nave from the sanctuary by a velvet curtain. The hidden sanctuary madubaha bears a strong resemblance to the garbhagriha (sanctum sanctorum) of the Hindu temples. However this division is also present in Greek orthodox churches where the iconostasis (wall of icons) separates the altar from the main nave. The ornamentation of the screen, which separates the sanctuary from the nave at St. Mary's church, evokes a certain Indian style.

The mural paintings on the wall of the madubaha (behind curtains) depict the crowning of Mary in an oval picture-frame with six panels. They illustrate the life of Christ, including scenes such as his birth, the adoration of the Magi, Mary and Elizabeth and the Annunciation. In the central row just below the coronation of Mary, there is representation of a crucifixion, and in the very centre Mary is portrayed with her child and resting her feet on a half moon (fig.10). This image of Mary as Immaculate Conception indicates that this cycle of paintings was executed during the Portuguese rule, since almost all Eastern Christians do not accept the Roman Catholic definition of the Immaculate Conception of Mary. Besides, Syrian Christians follow the doctrine of Nestorius. At the Council of Ephesus in 431 Nestorius strongly rejected the title Theotokos (Mother of God) for the Virgin Mary, and due to his teachings the Catholic Church eventually condemned Nestorians as heretical. ${ }^{5}$ Nestorians believe Mary is the mother of the human Jesus and not the divine one. During the following centuries the Virgin Mary acquired an even more almost divine status among the Roman Catholic Church, especially through the dogmas of the Immaculate Conception and the Assumption with her coronation as Queen of Heaven. The Catholic missionaries who disembarked in India brought with them many images and statues of the Virgin Mary. They promoted devotion to Our Lady, as they were all fervent devotees of different Marian cults: the Franciscans and Jesuits of the Immaculate Conception, the Dominicans of the Virgin of the Rosary, the Augustinians of Our Lady of Good Council. So Mary's image would exert a remarkable influence on the colonization of India in the sixteenth century and play a central role in the Church's mission to evangelize and civilize the masses during the following centuries. During the sixteenth and seventeenth century Mariology experienced a new flowering. Counter-Reformation art (1545-1563) was especially dedicated to the exaltation of the Virgin in order to defend the dogmas against attack by Protestants, especially the doctrines 
affirming her Divine Maternity and Immaculate Conception. Many new devotional texts were written. The Jesuits alone produced as many as 300 works on the Immaculate Conception between 1600 and 1800. ${ }^{6}$ Early in the seventeenth century, Catholic king Philip III of Spain dedicated the country to the Immaculate Conception of Mary. In 1646, Joao IV, the first Portuguese king of the Braganza dynasty, offered his crown to the Immaculate Conception. $^{7}$

The imagery of the Immaculate Conception merges with the image of the woman of the Apocalypse with passages from the Songs of Songs, Ecclesiasticus and other scriptures alluding to the spotlessness of the Virgin. The Immaculate Virgin was depicted as the woman of the apocalypse with a crescent moon under her feet, clothed with the sun and with a crown of twelve stars surrounding her, crushing a dragon or serpent, who is the symbol of evil.

Among the multiple and frequent representations of the Virgin in IndoPortuguese art are those recalling the Immaculate Conception. These are followed in number by representations of Our Lady with Child in her arms. The moon, habitual support of Our Lady in European images of the Immaculate Conception, becomes in Indo-Portuguese representation of Mary, a symbol of the Virgin, and thus it appears in images of Our Lady with Child, Our Lady of Sorrows, and Our Lady of the Rosary, Our Lady of Mercy etc. Mary seems to be almost always placed over the lunar crescent (fig. 11).

In the sixteenth and seventeenth century Mary will become the central focus of many Iberian retablos exactly like in this painted retablo of St Mary's church. The word retablo or retable originates from the Latin retrotabulum meaning the ornamental panel behind the altar. These altar retables retold narratives based on the Gospels. Retable art gained importance and began to grow not only in size but also in artistic splendour in the Iberian peninsula (Spain and Portugal) during the sixteenth and seventeenth centuries, and from there it was exported to their respective colonies. Among hagiographical themes, the Virgin Mary and local Iberian saints were widely popular. Particularly in areas recaptured from Islam, the Mother of God dominated retable iconography. These altar retables are a common feature of Catholic churches in Goa, the stronghold of the Portuguese Padroado.

Thus the painted retablo in the sanctuary with an Immaculate Conception at its centre was definitely conceived by the Portuguese clergy and executed by an Indian artist, and it must have been visible from the nave. The screen was probably added at a later date.

Above the altar archway appears a unique depiction of the fight between David and Goliath where the latter is dressed as a native king (fig. 8-9). In the biblical book of Samuel, Goliath is a giant Philistine defeated by the young David, the future king of Israel. In Judeo-Christian tradition, Goliath represents paganism, in contrast to David the champion of the God of Israel. Further, from the Christian perspective David prefigures Jesus' victory over sin on the cross. It is clear that the main object of this scene is to project the supremacy of Christianity over the local faith by showing the subjugation of a native Indian king.

Closer to the altarpiece wall, two panels show Abraham slaying Isaac on the left and Adam and Eve in the Garden of Eden on the right. (fig. 4-5) A creature looking like a makara is wrapped around the trunk of the Tree of 
knowledge. From this animal comes forth the devil offering Eva the forbidden fruit, which does not look like an apple, and it is probably an Indian persimmon, a common fruit in South Asia. ${ }^{8}$ Makara is an ancient mythological animal, a crocodile monster with teeth like the side tusks of a bear and a snout resembling the curled trunk of an elephant. Makaras have apotropaic powers; they avert evil spirits. In Hindu iconography a makara is the vahana (vehicle) of Ganga the river goddess and the water god Varuna. In South East Asia, makaras adorn lintels and arches of the temple's gate and are often depicted with a snake or a lion emerging from their mouth. In this way makaras guard over the entrance of a sacred place ${ }^{9}$ (fig. 6). The Indian artist (probably instructed by a Catholic priest) could have used this kind of creature because he interpreted the Genesis' snake as a guardian of the tree of the knowledge of good and evil. Snakes are usually associated with trees in India, and they are worshipped as divinities or in relation to a specific god. This scene, however, shows the makara-serpent with a European devil emerging from his gaping open mouth. This powerful image transforms a Hindu apotropaic symbol into a Christian symbol of evil, giving a negative connotation to this sacred animal. ${ }^{10}$

But the most interesting murals of this church are the two large compositions painted above the two entrance doors of the wall facing each other and depicting heaven and hell. The large panel of the "Vision of Heaven" shows Christ seated with Mary, St. John and his disciples. Above them God and angels are watching. In the next row below are a large number of angels trumpeting the arrival of the Son of God. Below them are the four doctors of the church and the four evangelists, all of them holding a plume pen. In the last two rows we find people wearing a crown probably representing the Kings of Israel; among them King David is holding his lyre. At the very bottom a number of people seems to be mesmerized by the holy vision.

The "Vision of Hell" is dominated by Satan who surprisingly resembles the goddess Bhagavati with trishul in hand and a crown of hooded snakes (fig. 12). Bhagavati is the Great Goddess of Kerala. Kerala religious predilections, her myths and her legends are all centred on the worship of the divine female aspect. Every Malayali knows that when the goddess Bhadrakali, commonly known as Bhagavati had killed the demon Darikan, Shiva requested that she go down to earth to protect his devotees. She chose Kerala as her domain. Kerala does not ignore male gods. There are several large beautiful temples dedicated to them, yet the true centre of her religious beliefs lies in the small kavus, the tiny shrines which were originally sacred sites in a grove of trees. It is in these kavus, even now that the worship of the goddess Bhagavati, (popular name for Bhadrakali or Kali) is most intense. ${ }^{11}$ She is shiny black or blue wearing a mala, a necklace of limes to cool her. She is ferocious with protruding tongue, wide eyes, a belt of severed arms and curved sharp teeth (fig.13). She wears a garland of severed heads. Bhagavati is autonomous, not married and usually understood to be a virgin. In various ritual contexts and sometimes spontaneously, men and women go into trance allowing Bhagavati to continually communicate her wishes. ${ }^{12}$ The multitude of Bhagavathy temples all along the coastal villages is a phenomenon one cannot miss.

Studies show that the cult of Devi was an ancient Dravidian cult prevalent along the Kerala cost and Tamil Nadu. Some scholars 
argue that Dravidian deities and rituals have become part of Hinduism while Brahmanic Hinduism has been equally changed by Dravidian religion. In the Hindu pantheon the male deities are predominant, and the female deities occupy a subordinate position. In the Dravidian cults of the South of India the virgin goddess is the most worshipped. These virgin goddesses are commonly said to be incarnations of Kali or Durga, and they are called gramadevatas. They are the guardians of the villages, they drive away epidemics and bring rain for the good harvest. Grama-devatas are identified with violence and sacrifice. As the source of death and new life, they have a nourishing and a destructive nature. ${ }^{13}$ One of the most widely worshipped grama-devatas in South India, and especially in the villages of Tamil Nadu is Mariamman, the goddess of smallpox. She has both the power to inflict and to remove epidemics and disasters, ${ }^{14}$ and Hindus, Christians and Muslims alike worship her. The same applies to the Goddess Bhagavathi, the most famous grama devata in Kerala, who is also called Naga Bhagavathi.

These goddesses usually wear a headdress of a polycephalus naga (serpent). So, serpents in the South of India are especially associated with the goddess, and like her they are also associated with water and fertility. In many legends Nagas are said to haunt lakes, ponds and river springs, and they are worshipped as water spirits or genii of lakes and springs.

When the European sailors and priests arrived in South India and saw these female divinities with long sharp fangs, adorned with freshly cut heads as a necklace, black or dark and naked, and a crowned head hooded with five serpents forms, they immediately thought they had encountered the devil, since some of their characteristics reminded them of Lucifer, the Evil One. In European works of art Satan is depicted like a dark or bluish monstrous creature with mask-like faces representing his sins on the joints of his knees and shoulders and sometimes on his chest, stomach or buttocks. He has twisting horns, and he has an open mouth dripping with the blood of the people he is eating (souls). In each of his outstretched hands he holds dead bodies. Sometimes he is represented with snakes entwined around his legs or sitting on a man-eating dragon.

With pictorial representations such as this which clearly resemble the virgin goddess of South India, it is easy to understand how the friars would associate these goddesses with the devil (fig.14-15). Moreover the Christian tradition from the very beginning incorporated ancient suspicions regarding women's association with evil and the devil. In the sixteenth century the religious outlook on women and the devil was shaped by officials of the Catholic Church, inquisitors and the clergy in general who recognized witchcraft as a common and dangerous part of Satan's concerted attack on all mankind. One of the most salient features of The Malleus Maleficarum ("The Witch's Hammer") written in 1486 is the description of the perverse nature of woman and her predisposition to participate in the work of the devil. This work, a veritable encyclopaedia of witchcraft, became the chief source of information about the characteristics and activities of witches, and its influence extended throughout Christian Europe. ${ }^{15}$

Clearly, the widespread cult of a female deity that Catholic priests encountered in Kerala prompted them to depict or order a representation of Hell with Bhagavati as Satan presiding over the underworld. By doing so, the 
friars intended to convey a clear message to the newly Hindu converts: their goddess was evil. This demonization of native deities was not new. The same strategy was used by religious orders in Latin America where pre-Hispanic goddesses and gods were portrayed as demons in colonial descriptions and representations.

The mural representing Hell is another visual proof that the wall decoration of St Mary's church at Angamaly was carried out under the supervision of Catholic priests. The tortures of Hell, the devil, the Immaculate Conception crushing a serpent or a dragon were common themes of Counter-Reformation art. These images were considered effective tools of evangelization in the new conquered lands.

Syrian tradition, on the contrary, does not employ representational art or even icons as in Greek orthodoxy. Most importantly the Eastern Orthodox Church never developed an aggressive or institutional mission such as Roman Catholics and Protestants have developed. The witness of the Orthodox is a quiet one, based more on worship and a holy life, than on preaching and proselytism.

As a result of this, Thomas Christians lived in harmony and mutual respect with nonChristian religious communities before the arrival of the Portuguese. These Indian Christians were very much integrated into the wider Hindu community, and they observed many of the Hindu social customs and practices. They had a position of privilege in Indian society, accepted and later on granted by local rulers. There were inter-marriages between Christians and Hindus in Kerala. The Hindu temples, Christian churches and even mosques co-existed near to each other. No restrictions or prohibitions prevented only
Hindus or only Christians attending functions inside their religious buildings. ${ }^{16}$

This is another reason why the wall decoration of St. Mary's Jacobite Syrian Church may be traced to Portuguese influences. Clearly the main objective here was to project the supremacy of Christianity over the local faith.

In St. Mary's Church, Catholic propaganda reaches its zenith in the representation of Hell where the Kerala goddess occupies the central position, while various sinners are being punished in the three rows below. The entire composition is depicted as if the action is taking place inside the open mouth of a huge snake or a monster (Leviathan). Baghavati-Satan is attended by two other devilish women who stand by her side, while monstrous creatures, snakes and poisonous insects are torturing the damned below.

With this powerful and frightening representation the Catholic friars intended to convince the natives that worship of their goddess would bring them only misfortune and Hell's tortures. However this image, which was a reflection of the friars' medieval and misogynist minds, conveyed an ambivalent message for the Hindu viewers. For them the goddess had destructive as well as creative powers and did not fit the univalent form of the medieval notion of the witch and the devil. Her awe-inspiring image did not scare them, since they knew she was the source of death but also of new life. She was the guardian deity of their villages. They could not abandon her, and so Baghavathy survived Catholic propaganda. The cult of this goddess is still very much alive in Kerala. Baghavathy continues to be worshipped all around Kerala in temples and kavu or "sacred groves". 
90 Patrizia Granziera

Each Spring Trivandrum (or Thiruvananthapuram), the capital city of Kerala, shuts down for a day while more than a million women of many religions, communities and classes line the streets with their pots to cook porridge, a women's offering to the goddess Bhagavati during her most important feast called Pongal. This festival entered the Guinness record for being the largest single gathering of women for a religious activity. Only women are allowed to participate in the Pongal ritual. Devotees from across the country and even from abroad participate in the ritual. ${ }^{17}$ So Christianity reached Kerala, but Bhagavathy the Great Goddess did not leave.

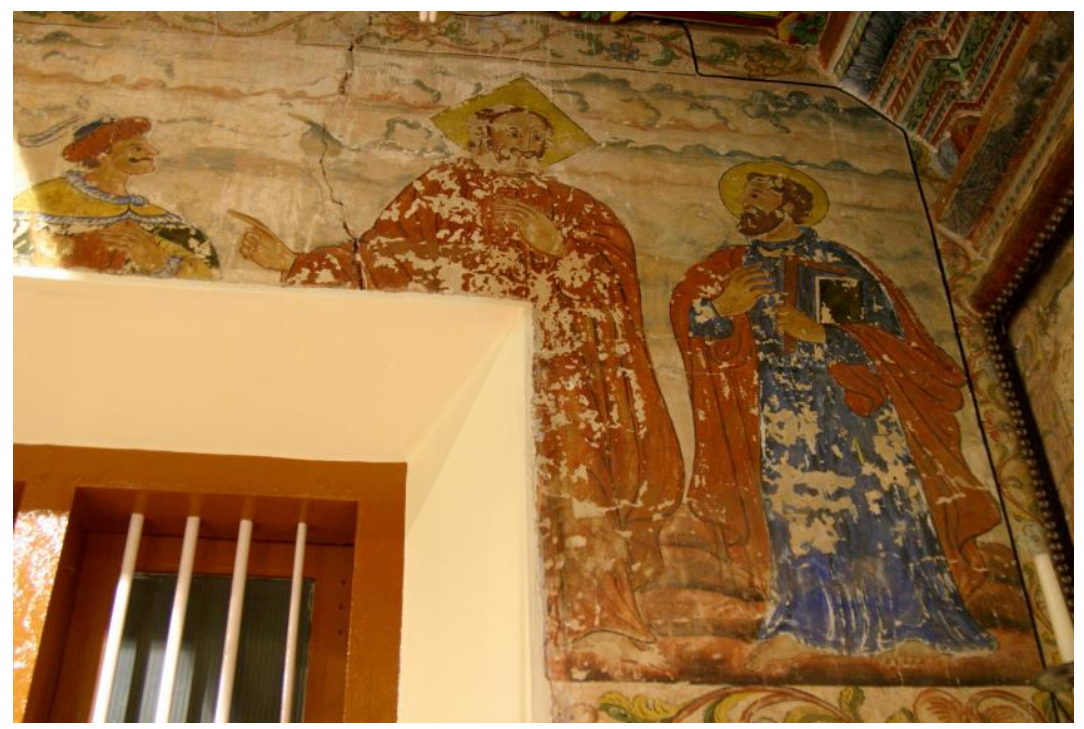

Fig. 1 Christ (centre) St Thomas (right) and an Indian belonging to a High caste (far left). St. Mary Jacobite Syrian Church Angamaly Kerala. Photo by the author.

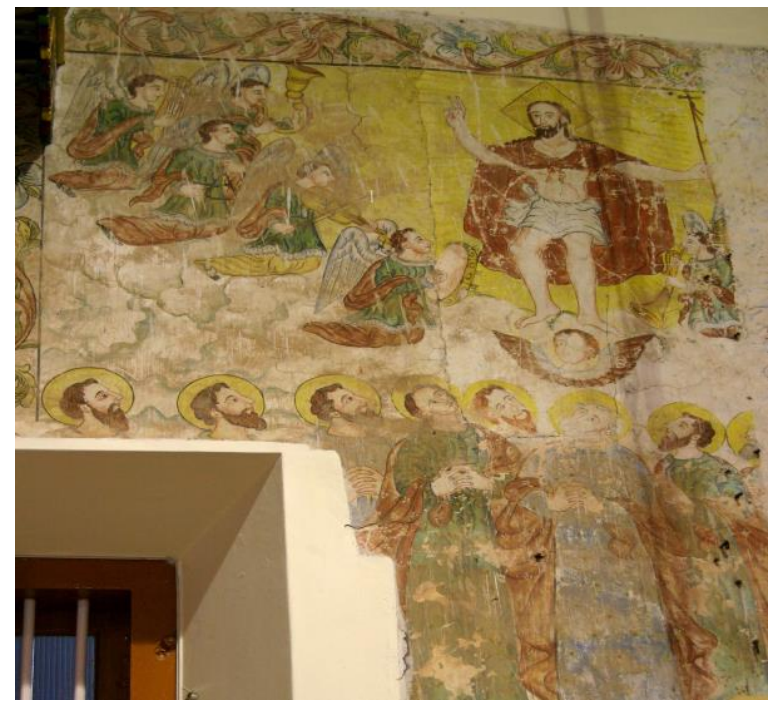

Fig. 2 Jesus Ascent to Heaven (right). St. Mary Jacobite Syrian Church Angamaly Kerala. Photo by the author. 


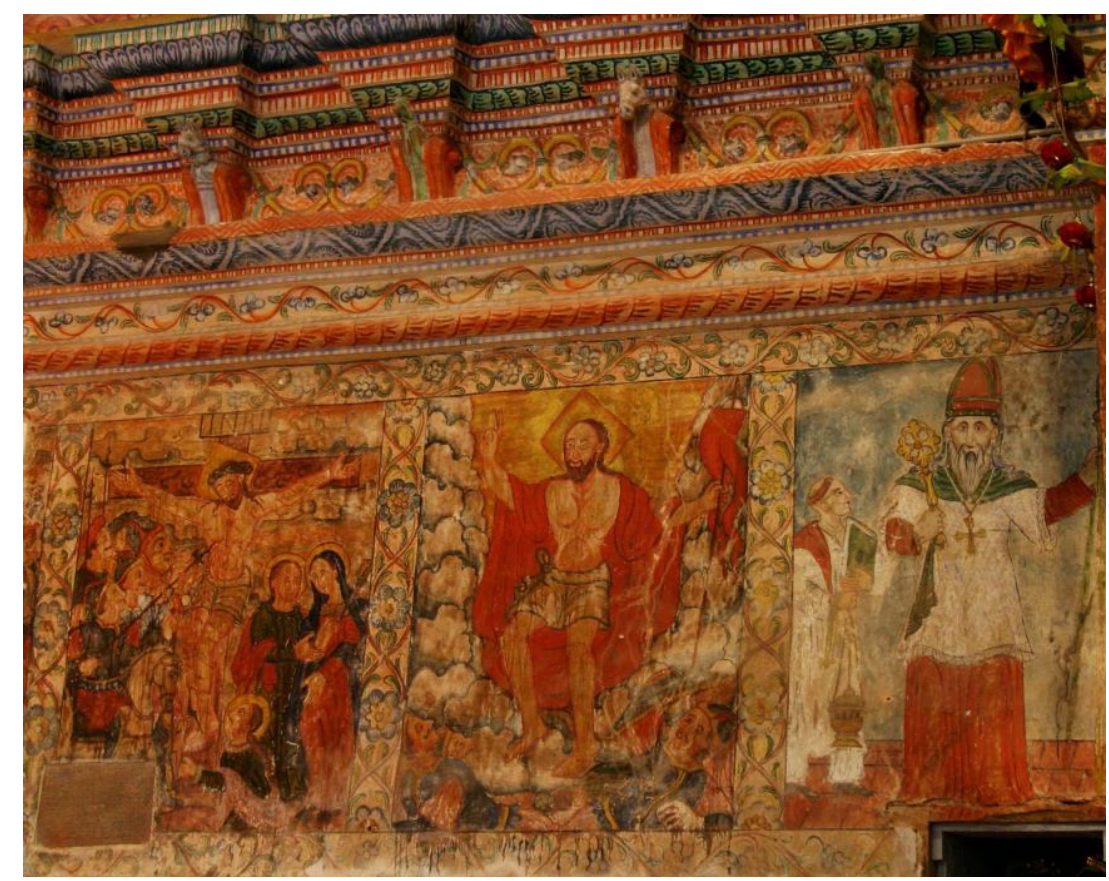

Fig. 3 Crucifixion, Resurrection and St. Mar Thoma (1653-1670) ? St. Mary Jacobite Syrian Church Angamaly Kerala. Photo by the author.

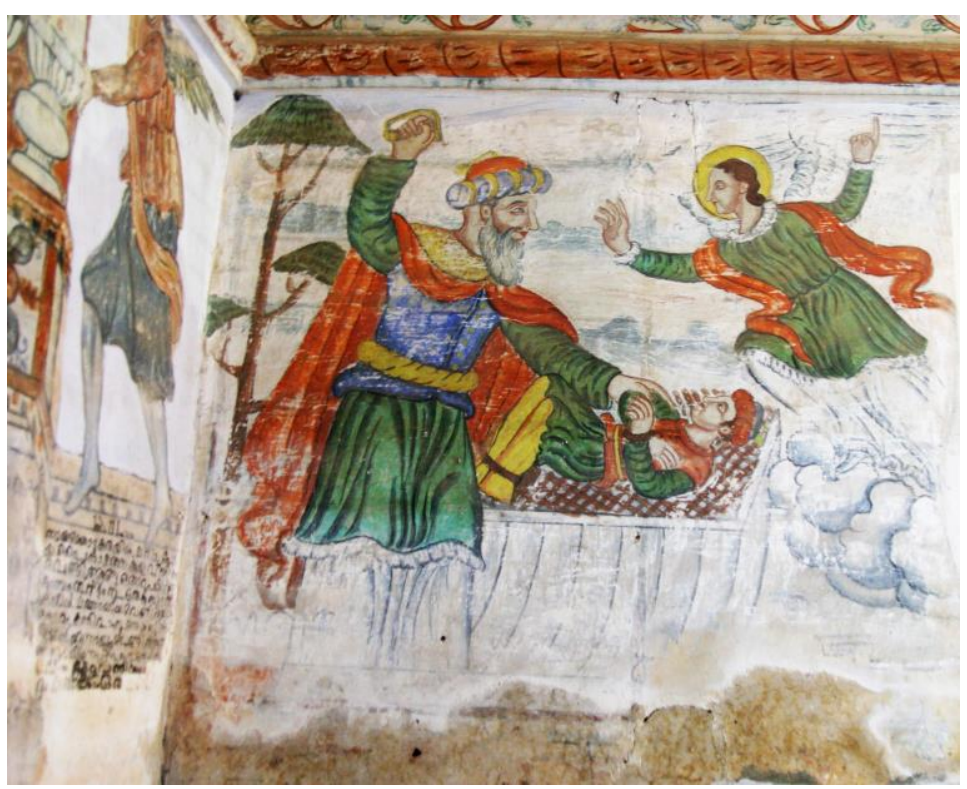

Fig. 4 Abraham and Isaac. St. Mary Jacobite Syrian Church Angamaly Kerala. Photo by the author. 


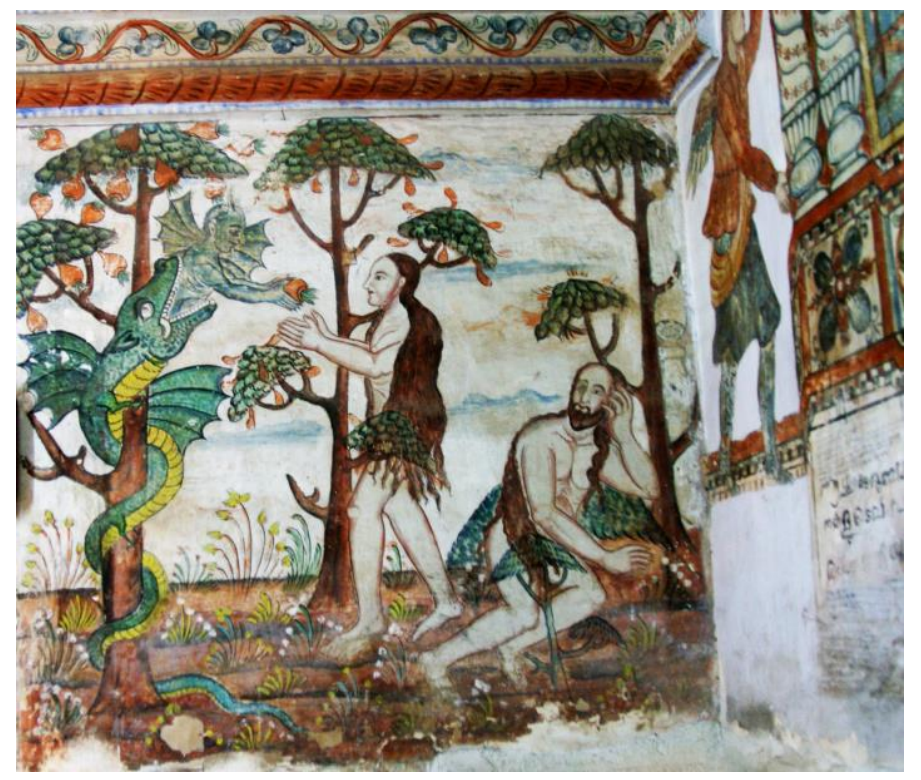

Fig. 5 Adam and Eve in the Garden of Eden. St. Mary Jacobite Syrian Church Angamaly Kerala. Photo by the author.

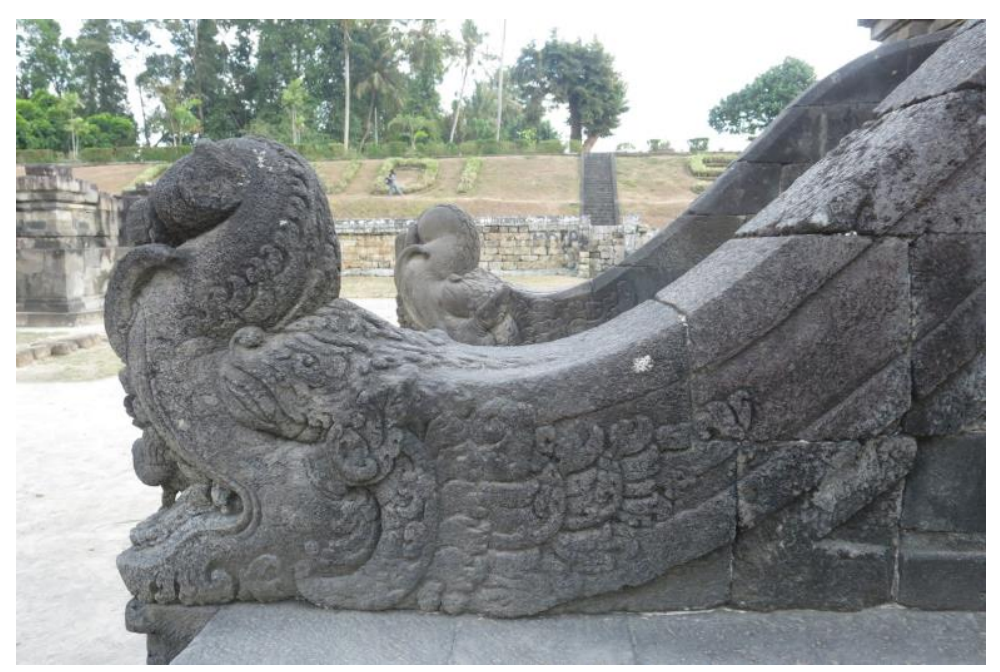

Fig. 6 Makara. Candi Sambisari, Java, Indonesia. Photo by the author. 


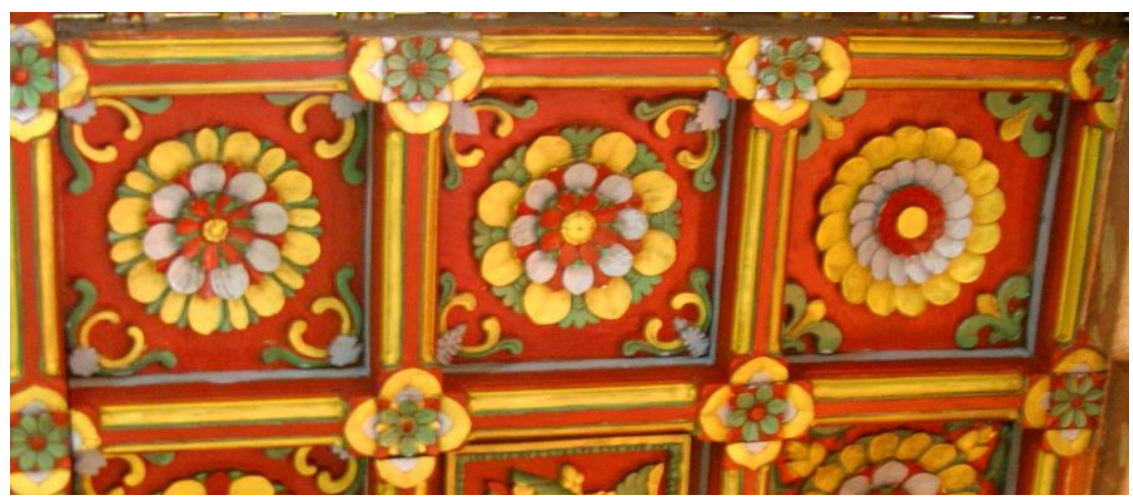

Fig. 7 Coffered ceiling. St. Mary Jacobite Syrian Church Angamaly Kerala. Photo by the author.

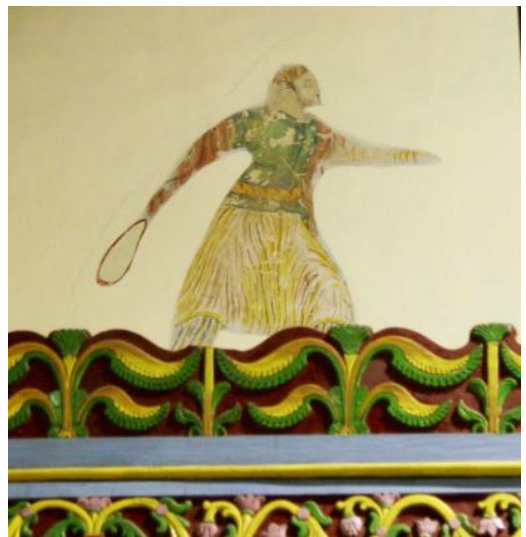

Fig. 8 David. St. Mary Jacobite Syrian Church Angamaly Kerala. Photo by the author.

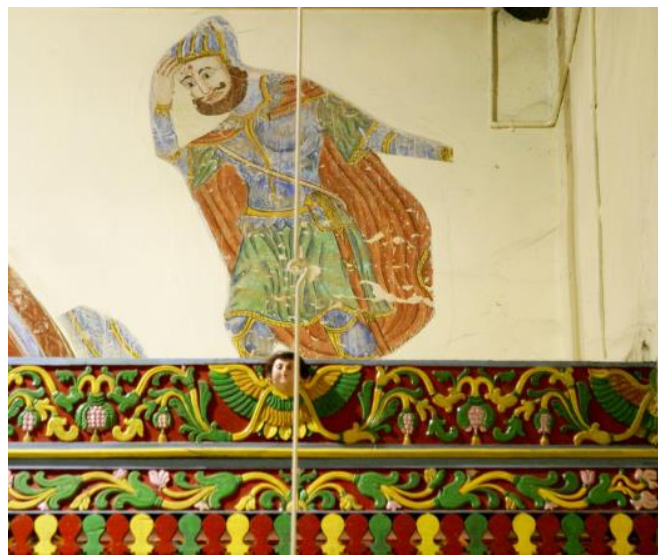

Fig. 9 Goliath. St. Mary Jacobite Syrian Church Angamaly Kerala. Photo by the author. 


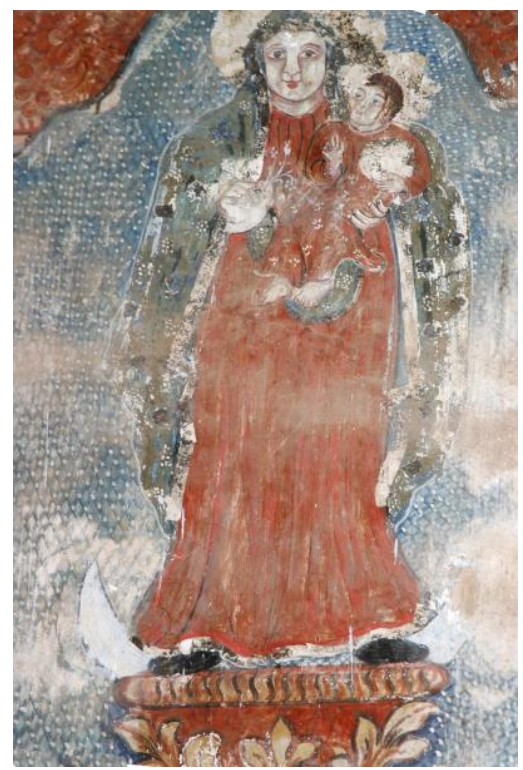

Fig. 10 Immaculate Conception with Infant Jesus at the centre of the painted retablo. St. Mary Jacobite Syrian Church Angamaly Kerala. Photo by the author.

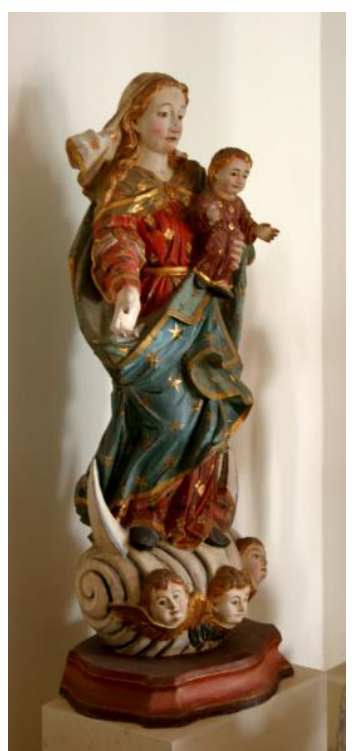

Fig. 11 Mary as Immaculate conception with Child. Indo-portuguese art. Museum of Christian Art, Cochin, Kerala, India XVII c. Photo by the author. 
Granziera: Cultural Interactions and Religious I conography in 16 th Century $\mathrm{K}$

Cultural Interactions and Religious Iconography in $16^{\text {th }}$ Century Kerala 95

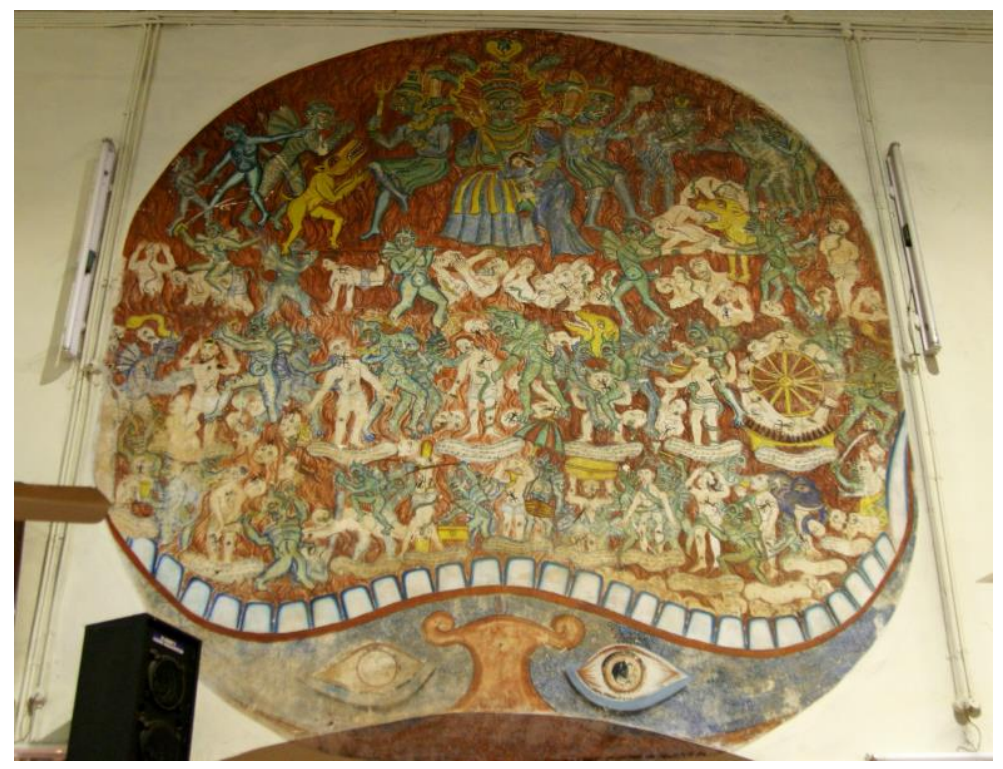

Fig. 12 Vision of Hell. St. Mary Jacobite Syrian Church Angamaly Kerala. Photo by the author.

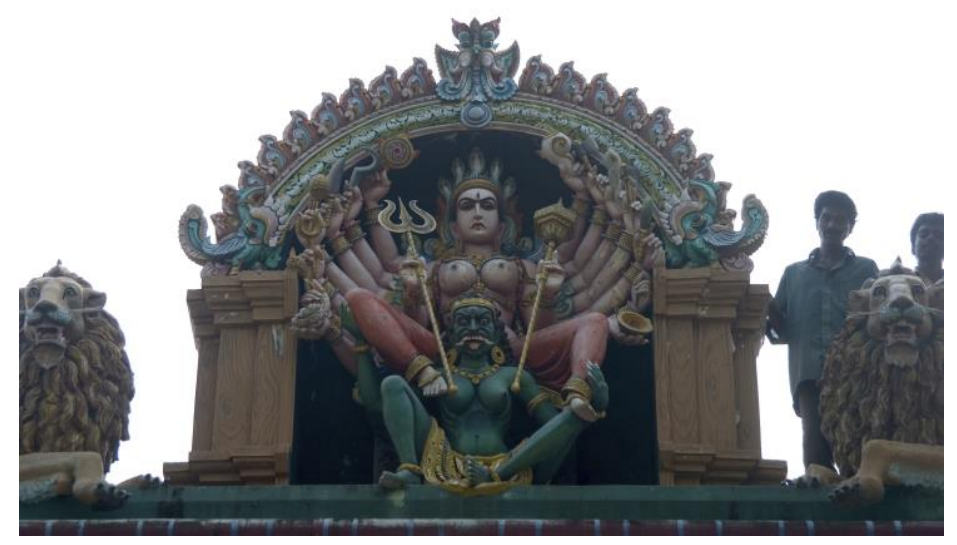

Fig. 13 Bhagavathi (Bhadrakali), Mandaikadu temple, Kerala. Photo by the author. 


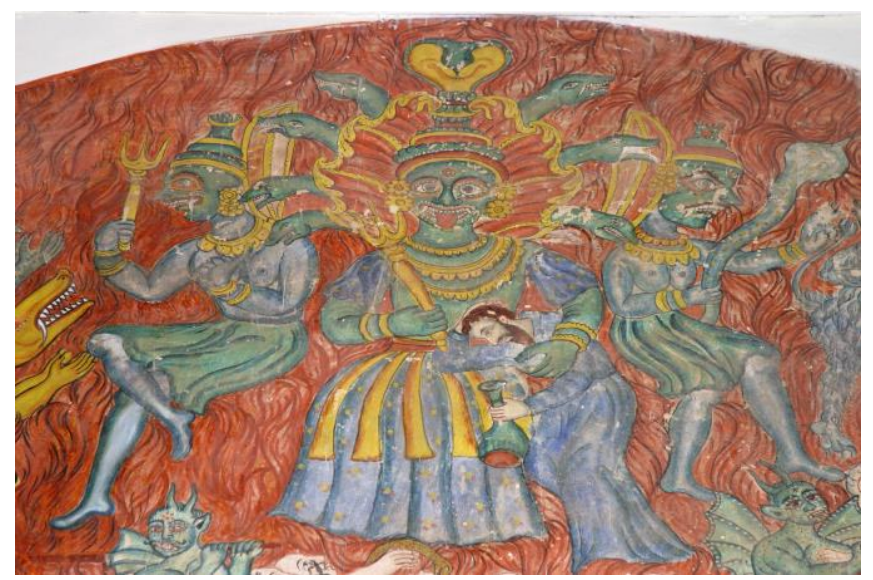

Fig. 14 Bhagavathi (Bhadrakali) as Satan. Detail of the "Vision of Hell." St. Mary Jacobite Syrian Church, Angamaly, Kerala. Photo by the author.

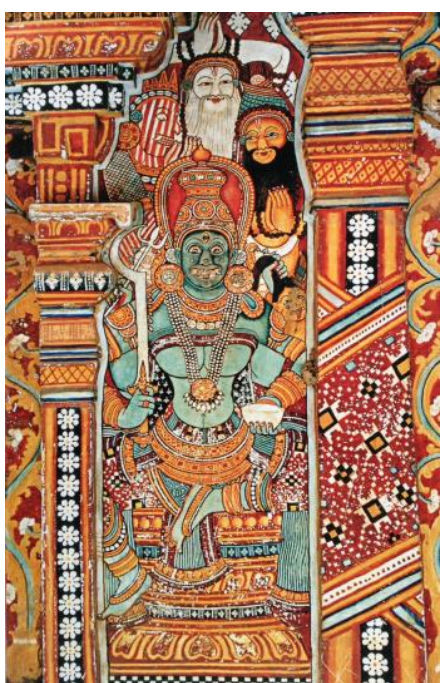

Fig. 15 Bhagavathi. Parayil Temple, Kuttipuram, Vadakara, Kozhikode District, Kerala. Photo by the author.

\section{Notes}

${ }^{1}$ The expansion of Christianity in the East, especially in India, was not the work of Hellenist Christian missionaries from Antioch or from any other areas within the former Roman Empire. It was the work of Jewish Christian missionaries such as Adai in Edessa, Aggai and Mari in Persia and St. Thomas in India. In the East Syrian Tradition, St. Thomas was the great Apostle. The Christian churches thus formed were ecclesiastically independent of Antioch or any other centre in the

West. It is difficult to present the pre-Portuguese history of St. Thomas Christians in India in a contiguous manner due to lack of sufficient historical records. But we get certain glimpses in the writings of foreign visitors, in the church traditions preserved in India and East Syria, occasionally in casual references by Indian writers, and from a few monuments and inscriptions. See Stephen Neil, A History of Christianity: The Beginnings to AD 1707 
(Cambridge: Cambridge University Press, 1984), 2634.

${ }^{2}$ Nestorianism is a christological doctrine advanced by Nestorious (386-450), Patriarch of Constantinople from 428-431. The doctrine emphasizes the disunion between the human and divine natures of Jesus. Nestorius' teachings brought him into conflict with some other prominent church leaders, most notably Cyril of Alexandria who criticized especially his rejection of the title Theotokos ("God-bearer") for the Virgin Mary. Nestorius and his teachings were eventually condemned as heretical at the First Council of Ephesus in 431 and the Council of Calchedon in 451, leading to the Nestorian Schism when churches supporting Nestorius broke with the rest of the Christian Church. Afterword many of Nestorius' supporters relocated to Sassanid Persia, where they affiliated with the local Christian community, known as the Church of the East. The Church of the East is part of the Syrian tradition of Eastern Christianity. It was the Christian church of the Persian Sasanian Empire and quickly spread widely throughout Asia. This Church was headed by the Patriarch of the East, continuing a line that, according to tradition, stretched back to the Apolostolic Age. Liturgically the church adhered to the East Syrian Rite, and theologically it adopted the doctrine of Nestorianism. From the sixth century on it expanded greatly, establishing communities in India (St. Thomas Christians), among the Mongol tribes in Central Asia, and China under the Tang Dynasty from the seventh to the ninth century.

${ }^{3}$ Francis Roz was the first Portuguese LatinRoman Catholic bishop. He ruled for 24 years over the Thomas Christians, after their subjection under the Udayamperoor Synod. During this time according to the principles directed by Udayamperoor he tried his best to Romanize and Latinize the Thomas Christians in worship, administrative system, custom, and discipline. The same continued to occur during the episcopates of his two successors Stephen Britto (1624-1641) and Francis Garzia (1641-1659). See Neil, History, 310-316.
${ }^{4}$ This is the Koonen Cross Oath considered as a famous declaration of freedom by the Church of the St. Thomas Christians. In this document they declared they would not obey the Church of Rome or the Portuguese or Jesuits, but only obey their Archdeacon. All historians agree that after the Oath practically the whole body of the Thomas Christians joined together against Roman Catholic supremacy. See Neil, History, 318-320.

${ }^{5}$ The theological view held by Nestorius, patriarch of Costantinople and a disciple of the Antioch school was that in Christ the two natures of God and man remained separate. Thus, he argued, Mary could be called Christotokos (Mother of Christ) since she was mother of Christ's humanity, but she should not be called Theotokos (Mother of God) because she was not the mother of his divinity. Cyril of Alexandria's school refuted the argument of Nestorius, emphasizing the unity of the person of Christ brought about by the incarnation, in which his divinity and humanity were inseparable. In agreeing with Cyril and declaring Mary to be Theotokos, the church affirmed the personal unity of Christ. Nestorius and his party were condemned as heretics. At the Council of Ephesus in $431 \mathrm{CE}$ the Virgin Mary was declared to be the mother of God (Theotokos), though this expression was not declared dogma by the early church. The conception of the immaculate Virgin Mary was established as a day of holy obligation in 1708. See Emil Nuebert, Mary in Doctrine (Milwaukee: The Bruce publishing Company, 1954), 21-25.

${ }^{6}$ Michael O'Carroll, Theotokos: A Theological Encyclopedia of the Blessed Virgin Mary (Wilmington: Michael Glazier Inc. 1983), 181.

${ }^{7}$ At the University of Coimbra in Portugal when a student received a degree he/she would traditionally swear to defend the prerogatives of the Immaculate Conception criticised by the Protestants. This custom was kept until the establishment of the Republic in 1910. Mons. Miguel de Oliveira, Nossa Sehhora Na Devoçao Dos Reis e Governantes in A Virgem e Portugal, ed. by Fernando de Castro Pires de Lima, (Porto: Ediçoe Ouro 1967), 100. 
${ }^{8}$ Diospyros malabarica, commonly known as Indian persimmon or Malabar ebony, is an evergreen tree whose bark is almost black with an egg-shaped yellowish/orange fruit. This tree is very common in South Asia. Infusion of pulp is used for dying fish nets and making them more durable and for caulking on boats. Bark and seeds are used in medicine. See Mangrove Guidebooks for Southeast Asia, ed. by Wim Giesen and others, (Bangkok: FAO and Wetlands international Thailand, 2006), 171.

${ }^{9}$ Krishna K. Murthy Mythical Animals in Indian Art, (New Delhi: Abinav Publications, 1985), 46-47.

${ }^{10}$ In Hindu temples, the Makara often serves as the structural bookends of a thoranam or archway around a deity. The arch emerges up from the jaws of one makara, rises to its peak, the kirtimukha ('face of glory'), and descends into the gaping jaws of another makara. Makaras are usually part of the decorative carving on a lintel, tympanum, or wall and are usually depicted with other symbolic animals, such as lions or serpents emerging from its gaping open mouth. The makara has appeared in Indian and Buddhist art from ancient times: on temple pots, on rare pre-Kusana (1st century BCE, in the region that is now Afghanistan) coins, on temple walls, as a sculptured waterspout. The makara is usually regarded as a soma animal: an emblem of the waters, the plants, the entire vegetal substratum of life.

${ }^{11}$ M.J. Gentes, "Scandalizing the Goddess at Kondungallur," Asian Folklore Studies 51:22 (1992):295322, especially 298-301.

${ }^{12}$ Elaborated in many versions, the basic story of Bhadrakali is that an asura (male demon) named Darikan, after undergoing arduous penance, asked the god Brahma to grant him the boon of immortality. Brahma asked Darikan whether he also desired immunity from women, but Darikan contemptuously rejected the offer. Darikan proceded to go on a rampage of destruction so horrible that the whole world and all the gods petitioned the god Siva to save the Universe. Siva used his energy to call forth from his third eye the goddess Bhadrakali, who battled the demon and finally killed him by cutting off his head, thus restoring order to the world. During the pre-monsoon hot season, between January and April, performance rituals reenacting some parts of this story are held in most Devi temples in Kerala.

${ }^{13}$ R. Nagaswamy, Tantric Cult of South India, (New Delhi: Agam Kala Prakashan, 1982), 2-6.

${ }^{14}$ Mariamman is also known as Muttu (pearls) Mari. Popular etymology defines Mari as rain, which cools down the heat of the land and cures smallpox and chickenpox, which are considered to be heatoriginated epidemics. Rain also brings good harvest. The title Muttu added to her name Mari implies her dichotomus character, as she brings raindrops for a good harvest as well as pearl-like chickenpox to decorate the body of the people. See Y. Nishimura, A Study on Mariyamman Worship in South India (Tokyo: IICAA, 1987), 3-11.

${ }^{15}$ This work, which ran into at least fourteen editions before 1520 and which did so much not only to establish the feminine image of the witch but also to link women with evil and the work of the devil, was written in Latin and accessible to clergy not only in Germany, the land of its Dominican authors, but in Spain as well.

${ }^{16}$ See Anand Amaladass SJ and Gudrun Löwner, Christian Themes in Indian Art: From the Mughal Times to the Present (New Delhi:_Manohar, Publishers, 2011), 17. From different centuries various copper plates have survived, documenting the privileges granted to Thomas Christians by local rulers. One plate might be already from $230 \mathrm{CE}$, others around 750 and later. Many privileges such as the right to keep slaves, to ride on elephants, to collect taxes in certain areas, to have baldachin carries are enlisted there. They helped the Christians to live on a level similar to the local nobility and the Brahmins. The Christians formed something like a caste by themselves and showed very little interest in mission. The first churches were built in teakwood and in front of them stone crosses were erected as signposts. One of the few churches surviving from the time before the arrival of the Portuguese is in Kalloopara/Kerala and shows beyond doubt that between the 8th and the 15th century a close link existed between Hindu and 
Christian architecture. See Amaladass and Lowner, 13-15.

${ }^{17}$ Diana Jennet, "A Million Shaktis Rising: Pongala, a Women's festival in Kerala," in Journal of Feminist Studies in Religion 21:1, (2005):35-55, especially 45-50. Pongala (literally meaning to boil over) is a ritualistic offering of a sweet dish consisting of rice porridge, sweet brown molasses, coconut gratings, nuts and raisins. Devotees offer pongala to appease the presiding deity of the Attukal temple Bhagavaty - popularly known as Attukalamma. 